\section{Diabetes Alert Day — March 22, 2016}

March 22 is Diabetes Alert Day, dedicated to raising awareness about type 2 diabetes, its risk factors, and its prevention. Type 2 diabetes, which accounts for $90 \%-95 \%$ of all cases of diagnosed diabetes in U.S. adults, might be prevented through lifestyle changes, such as losing weight and increasing physical activity $(1,2)$. In the United States, 86 million adults have prediabetes, putting them at increased risk for developing type 2 diabetes, heart disease, and stroke. Only $10 \%$ of adults with prediabetes know they have it $(1,3)$.

In partnership with the Ad Council, the American Diabetes Association, and the American Medical Association, CDC's Division of Diabetes Translation developed and launched the first national prediabetes awareness campaign to encourage people to take steps to prevent type 2 diabetes. The website DoIHavePrediabetes.org (https://doihaveprediabetes.org) features a short test for people to find out their prediabetes risk and includes lifestyle tips and links to CDC-recognized prevention programs across the country that are part of the National Diabetes Prevention Program (http://www.cdc. gov/diabetes/prevention/index.html). The U.S. Diabetes Surveillance System includes an updated Diabetes State Atlas (http://www.cdc.gov/diabetes/data) that allows users to view data and trends on any mobile device. In addition to containing the latest state-level data, the atlas now presents estimates of the percentage of adults without diagnosed diabetes who report having had a test for diabetes or high blood glucose in the past 3 years. Additional information about diabetes prevention and control is available from CDC (http://www.cdc.gov/diabetes).

\section{References}

1. CDC. National diabetes statistics report: estimates of diabetes and its burden in the United States, 2014. Atlanta, GA: US Department of Health and Human Services, CDC; 2014.

2. Knowler WC, Barrett-Connor E, Fowler SE, et al.; Diabetes Prevention Program Research Group. Reduction in the incidence of type 2 diabetes with lifestyle intervention or metformin. N Engl J Med 2002;346:393403. http://dx.doi.org/10.1056/NEJMoa012512

3. Li YF, Geiss LS, Burrows NR, Rolka DB, Albright A. Awareness of prediabetes-United States, 2005-2010. MMWR Morb Mortal Wkly Rep 2013;62:209-12.

\section{World Water Day — March 22, 2016}

World Water Day 2016, sponsored by the United Nations, is focused on water and jobs. Approximately half of workers around the world ( 1.5 billion persons) have jobs in waterrelated industries (1). Many industries rely on water to perform jobs, such as fishing, agriculture, manufacturing, and food service. Societies and economies depend on the men and women who work to keep the world's drinking water safe.

Climate change affects the economies and infrastructure that provide access to safe drinking water around the world. The World Health Organization estimates that during 2030-2050, an additional 250,000 persons will die each year as a result of climate change (2). Diarrheal diseases from contaminated water and lack of adequate sanitation and hygiene will be a major cause of these additional deaths (3). Now is the time to address these challenges and commit to the responsible management of water resources to ensure sustainable development in the present and for generations to come.

Information is available about World Water Day, including ideas on how to get involved (http://www.unwater.org/ worldwaterday). Information on CDC's efforts to ensure global access to improved water, sanitation, and hygiene is also available (http://www.cdc.gov/healthywater/global).

\section{References}

1. United Nations. World Water Day. New York, NY: United Nations; 2016. http://www.unwater.org/worldwaterday

2. World Health Organization. Economic, social and environmental context of health [Chapter 2]. In: Health in 2015: from MDGs (millennium development goals) to SDGs (sustainable development goals). Geneva, Switzerland: World Health Organization; 2015. http://www.who.int/gho/ publications/mdgs-sdgs/MDGs-SDGs2015_chapter2.pdf

3. World Health Organization. Infectious diseases [Chapter 5]. In: Health in 2015: from MDGs (millennium development goals) to SDGs (sustainable development goals). Geneva, Switzerland: World Health Organization; 2015. http://www.who.int/gho/publications/mdgs-sdgs/ MDGs-SDGs2015_chapter5.pdf?ua=1 